\title{
Habitat selection by terrestrial birds on Pemba Island (Tanzania), with particular reference to six endemic taxa
}

\author{
Paulo Catry a,b,*, Richard Mellanby ${ }^{\mathrm{c}}$, K. Ali. Suleiman ${ }^{\mathrm{d}}$, K. Haji Salim ${ }^{\mathrm{d}}$, \\ M. Hughes ${ }^{\mathrm{c}}$, M. McKean ${ }^{\mathrm{c}}, \mathrm{N}$. Anderson ${ }^{\mathrm{c}}, \mathrm{G}$. Constant ${ }^{\mathrm{c}}, \mathrm{V}$. Heany ${ }^{\mathrm{c}}$, \\ G. Martin ${ }^{\mathrm{c}}, \mathrm{M}$. Armitage ${ }^{\mathrm{c}}, \mathrm{M}$. Wilson ${ }^{\mathrm{c}}$ \\ ${ }^{a}$ Unidade de Investigação em Eco-Etologia, ISPA, R. Jardim do Tabaco 44, 1100 Lisboa, Portugal \\ ${ }^{\mathrm{b}}$ Edward Grey Institute of Ornithology, Zoology Department, University of Oxford, UK \\ ${ }^{c}$ Project Pemba. Glasgow University Expedition 1998. IBLS, University of Glasgow, Glasgow G12 8QQ, UK \\ ${ }^{\mathrm{d}}$ Commission for Natural Resources, PO Box 283, Wete-Pemba, Tanzania
}

Received 16 September 1999; received in revised form 9 February 2000; accepted 8 March 2000

\begin{abstract}
An important proportion of the world's biodiversity is found on oceanic islands. Island endemics frequently have small populations and are known to be sensitive to habitat and community changes, making them prone to extinction. In this paper, we assess the habitat distribution of the terrestrial birds of Pemba, an oceanic island that has been classified has an "Endemic Bird Area". Most of Pemba has been profoundly altered by human activities and only small patches of natural vegetation remain. However, we found that the six endemic birds (four species and two sub-species) have colonised several of the man-made habitats, including clove plantations and farmland, and remain widespread. Species richness was not reduced in these heavily managed areas when compared to the remnants of tropical forest. Nonetheless, the main strongholds of some endemic species are in habitats which have substantially declined in recent years, and which are likely to be further reduced in area in the medium and long term. For these endemics, particularly the Pemba scops owl (Otus pembaensis), the conversion of areas that were formerly clove plantations to open farmland should be considered a serious threat. (C) 2000 Elsevier Science Ltd. All rights reserved.
\end{abstract}

Keywords: Endemic birds; Habitat selection; Oceanic island; Pemba

\section{Introduction}

A sizeable proportion of the world's biodiversity is found on oceanic islands, in spite of the fact that they represent only a very small fraction of the total surface of the earth (ICBP, 1992). Small populations and long periods without contact with aggressive predators, parasites and competitors make island endemics particularly vulnerable. In fact, the vast majority of bird species known to have become extinct in pre-historic and historical times were island endemics (Newton, 1998). Many disappeared long before they were scientifically described and their natural history was never studied.

* Corresponding author at present address: IUCN Office, Apartado 23, 1031 Bissau Codex, Guinea-Bissau.

E-mail address: tartaruga@sol.gtelecom.gw (P. Catry).
The Island of Pemba lies just $50 \mathrm{~km}$ off the African Coast, in the Indian Ocean. Unlike its neighbour Zanzibar, Pemba is thought to have been isolated from the continent by a deep channel for several million years, and is classified as a true oceanic island (Archer and Turner, 1993). It has a relatively high number of endemic taxa, including higher plants, insects, amphibians, reptiles, mammals and birds. Pemba is classified as one of the 218 Endemic Bird Areas of the World (Stattersfield et al., 1998). The island is densely populated by people, and most of the natural forest cover has been cleared for clove plantations (Syzygium aromaticum) and other agricultural use. Only small areas of indigenous forest are left (Burgess et al., 1992). Further deforestation might pose a threat to the island's endemic flora and fauna, if species cannot adapt to the new environments prevailing in most of their potential natural range. The four species of endemic birds of Pemba are not currently classified as threatened (Collar et al., 
1994), although del Hoyo et al. (1996) refer to the Pemba green pigeon (Treron pembaensis) as near-threatened.

Although there are several descriptions of the avifauna of Pemba (Vaughan, 1929, 1930; Pakenham, 1979; Archer and Turner, 1993), no quantitative data has been published on their habitat selection. In this paper we present data on habitat use by the terrestrial birds of Pemba (excluding species associated with wetlands), with particular emphasis on the six endemic species or subspecies (Zimmerman et al., 1996). Our primary aim was to assess the degree to which these species have adapted to the new man-made habitats. We also discuss the potential impact of further predictable changes in land use on the conservation of the endemic birds.

\section{Study area}

Pemba is low lying, reaching just c. $100 \mathrm{~m}$ at the highest point, with a topography characterised by numerous small valleys and hills. The island has a total surface area of $1040 \mathrm{~km}^{2}$ (Pakenham, 1979). The climate is tropical with a mean rainfall of c. $1860 \mathrm{~mm}$ per annum, which falls mostly between March and May ("long rains") and November and December ("short rains"). Temperature varies between 21 and $34^{\circ} \mathrm{C}$ (Beentje, 1990). It has a high human population (c. 280 $\mathrm{km}^{-2}$ ) that is rapidly increasing (Stattersfield et al., 1998). Originally, Pemba is thought to have been covered almost entirely by forest, but most of this has been cleared for agroforestry plantations.

Presently, four main habitat types can be recognised:

- Tropical moist forest - Tall forest, growing in deep humus, with canopy height ranging from c. $20 \mathrm{~m}$ in coastal thicket to $25-35 \mathrm{~m}$ in the interior. It is dominated by Odyendea zimmermannii, with common associates including Antiaris toxicaria, Bombax rhodognaphalon, Croton sylvaticus, Elaeis guineensis, Erythrophloeum suaveolens, Pachystela brevipes and Uapaca guineensis. Barringtonia racemosa and Raphia farinifera are common in swampy areas or near pools (Beentje, 1990). Many trees support heavy growths of lianas and epiphytes. Undergrowth is dense near forest edges and paths, but sparser in less disturbed areas. Little of this forest type remains, with the largest patch (c. 750 ha) left in the Ngezi Forest Nature Reserve (Abdullah et al., 1996), where most of the forest censuses were carried out.

- Coastal rag scrub - Dry scrub on uplifted coral beds with very shallow sandy soils. The shrub canopy is generally $2-3 \mathrm{~m}$ high, composed largely of Acacia spp., Commiphora lindensis and Sor- indeia madagascariensis, with expanses of secondary Psidia arabica, Calotropis procera, and Lantana camara, and plantations of Casuarina equisetifolia. Occasional stands of Borassus flabellifera palms and baobabs (Adansonia digitata) are found. Coral rag vegetation (including two small remnants of coral rag forest; see below) covers c. $12 \%$ of the surface of the island (Leskinen et al., 1997).

- Clove plantations - These vary from pure stands of clove trees to plantations with small gaps for cultivation and several other trees (e.g. Elaeis guineensis) growing amongst the cloves. The canopy is up to $20 \mathrm{~m}$ high, climbers are common and undergrowth is often dense. There are no estimates of the total extent of clove plantations in Pemba, but agroforestry areas represent a very large proportion $(44 \%)$ of the island surface, of which the clove is the primary crop (Leskinen et al., 1997).

- Farmland - This is a more open landscape, mostly with small scale cultivation, predominantly cassava (Manihot esculenta), with scattered groves of coconut (Cocos nucifera), mango (Mangifera indica), banana (Musa spp.) and cloves.

Other smaller habitats surveyed included a rubber (Hevea brasiliensis) plantation and a coral rag forest with canopy height about 10-12 m, dominated by Manilkara sansibarensis, Mimusops obtusifolia and Diospyros consolatae. We also sampled ecotones between habitats, including stretches of mangrove swamps and heathland of Philippia mafiensis. These data are presented only pooled in the island summaries, as birds could not be assigned to a specific habitat in ecotones.

\section{Methods}

\subsection{Birds}

Fieldwork on Pemba was carried out between 22 October and 5 December 1998, during a time of the year when most bird species should be breeding (Pakenham, 1979). The first 2 weeks of this period were spent learning the vocalisations of the birds under the tutelage of local members of the expedition. We attempted to determine densities of all the land birds in representative habitats by carrying out point counts with two distance bands, with the cutting point set at $25 \mathrm{~m}$ (Bibby et al., 1992). In each point count we waited for $15 \mathrm{~min}$ and recorded all birds seen or heard. Counts were made from sunrise until $3 \mathrm{~h}$ later, and not under unfavourable weather (strong wind or rain). All counts were made by at least three observers, including one of the experienced local researchers.

Pemba scops owls (Otus pembaensis) were censused in the first 2 hours after dark using a playback method. 
The call of this species was played from a tape for one minute, after which we recorded all the birds heard within the next $3 \mathrm{~min}$. For logistical reasons, evening point counts were performed at different locations from those carried out during the day. All point counts were spaced in such a way that avoided the same individuals being recorded in more than one count.

\subsection{Habitat classification and variables}

After choosing the general area where to carry out a point count, we attempted to select the precise observation spot in a random way. This was achieved by randomly choosing a number of steps to walk along our path until we reached the observation spot. At each spot we measured the following habitat variables:

- TREEDIST1 - distance from the observer to the nearest tree (with circumference at chest height $>40 \mathrm{~cm}$. This size criterion applies to all DIST variables below).

- TREEDIST2 - distance from the nearest tree (above) to its nearest neighbour.

- COCODIST1 - distance from the observer to the nearest coconut tree.

- COCODIST2 - distance from this tree to the nearest neighbouring coconut tree.

- CLOVEDIST1 - distance from the observer to the nearest clove tree.

- CLOVEDIST2 - distance from this tree to the nearest neighbouring clove tree.

- CANOPY - percentage canopy cover

- UNDERGROWTH - percentage of undergrowth cover in a radius of $25 \mathrm{~m}$ around the observer.

When the distance to the nearest tree exceeded $50 \mathrm{~m}$ (often visibility was lower than this), a value of $51 \mathrm{~m}$ was assigned for the appropriate variable.

\subsection{Analysis}

To compare the abundance of species in different habitats, we calculated the proportion of point counts per habitat in which the species was detected. Frequency data are known to correlate well with actual abundance, provided that maximum frequencies $(1.0$, or $100 \%)$ are not often attained (e.g. Gibbons et al., 1993). This approach also reduces the bias resulting from a greater ability to detect more individuals by sight in flocks or family groups in open habitats. However, our frequency estimates are still biased towards habitats with a greater visibility, and this needs to be taken into account when interpreting the data. We performed the same analyses using total number of individuals counted, but the results were qualitatively very similar to the ones obtained by presence/absence data. For the Pemba scops owl we presented the absolute counts instead of frequency data since all birds were heard rather than seen, and habitat structure is thought to have a low influence on detectability.

We calculated an index of tree density given by TREEDENS $=1 /[($ TREEDIST $1+$ TREEDIST2 $) / 2]$.

The same procedure was used to calculate indices of coconut-tree density (COCODENS) and clove-tree density (CLOVE DENS). These new habitat variables, together with CANOPY and UNDERGROWTH were used in multiple logistic regressions with each of the six endemic bird taxa as dependent variables. Significance levels were assessed using log likelihood-ratio tests. Means are presented with standard deviations.

\section{Results}

\subsection{Species richness and habitat use}

A preliminary tabulation of the data revealed that relatively more birds were recorded within the $25 \mathrm{~m}$ boundary than beyond it in more open habitats (farmland) than in closed ones (primary forest; Table 1). This is the opposite to what we would expect, since in habitats with low visibility the proportion of birds present that are detected should decrease more rapidly with increasing distance. The above mentioned pattern most likely results from a systematic error in estimating the distance from the observers to the birds heard but not seen. As this type of error would have a strong influence on any density estimates for the species under study, we refrained from performing such analyses.

A median number of seven bird species was detected in each point count, with no significant difference between the four main habitats surveyed (KruskallWallis test: $\left.\chi^{2}=7.01,3 \mathrm{df}, P=0.07\right)$. However, farmland supported a higher cumulative species diversity when compared to other habitats (Fig. 1).

Table 2 shows the habitat distribution of the terrestrial birds encountered during systematic point counts

Table 1

Number of individuals of the five endemic diurnal birds of Pemba recorded within and beyond the $25 \mathrm{~m}$ distance limit during point counts in farmland (106 counts) and closed forest (59 counts) ${ }^{\mathrm{a}}$

\begin{tabular}{|c|c|c|c|c|c|}
\hline & Goshawk & Pigeon** & Starling & Sunbird* & Whiteye \\
\hline \multicolumn{6}{|l|}{ Forest } \\
\hline Within $25 \mathrm{~m}$ & $2(10 \%)$ & $4(13 \%)$ & $16(32 \%)$ & $31(46 \%)$ & $13(29 \%)$ \\
\hline Beyond $25 \mathrm{~m}$ & $19(90 \%)$ & $26(87 \%)$ & $34(68 \%)$ & $36(54 \%)$ & $32(71 \%)$ \\
\hline \multicolumn{6}{|c|}{ Farmland } \\
\hline Within $25 \mathrm{~m}$ & $2(13 \%)$ & $9(56 \%)$ & $2(50 \%)$ & $137(61 \%)$ & $23(27 \%)$ \\
\hline Beyond $25 \mathrm{~m}$ & $13(87 \%)$ & $7(44 \%)$ & $2(50 \%)$ & $88(39 \%)$ & $40(73 \%)$ \\
\hline
\end{tabular}


Table 2

Habitat distribution of Pemba terrestrial birds as revealed by frequency of detection in 15 min point counts

\begin{tabular}{|c|c|c|c|c|c|c|}
\hline Habitat & Forest & Cloves & Farm & Scrub & Rubber & Coral rag forest \\
\hline Number of point counts & 59 & 102 & 106 & 41 & 15 & 11 \\
\hline $\begin{array}{l}\text { Hadada ibis } \\
\text { Bostrychia hagedash }\end{array}$ & 0.07 & 0.05 & 0 & 0.05 & 0.07 & 0.18 \\
\hline $\begin{array}{l}\text { Striated heron } \\
\text { Butorides striatus }\end{array}$ & 0 & 0.07 & 0.13 & 0.12 & 0.13 & 0 \\
\hline $\begin{array}{l}\text { Cattle egret } \\
\text { Bubulcus ibis }\end{array}$ & 0 & 0.21 & 0.43 & 0.05 & 0 & 0 \\
\hline $\begin{array}{l}\text { Palm-nut vulture } \\
\text { Gypohierax angolensis }\end{array}$ & 0.17 & 0.02 & 0.08 & 0 & 0.07 & 0 \\
\hline $\begin{array}{l}\text { Black kite } \\
\text { Milvus migrans parasiticus }\end{array}$ & 0 & 0 & 0.02 & 0 & 0 & 0 \\
\hline $\begin{array}{l}\text { African harrier-hawk } \\
\text { Polyboroides typus }\end{array}$ & 0.14 & 0.13 & 0.08 & 0 & 0 & 0 \\
\hline $\begin{array}{l}\text { Pemba African goshawk } \\
\text { Accipiter tachiro pembaensis }\end{array}$ & 0.39 & 0.24 & 0.14 & 0.07 & 0 & 0.27 \\
\hline $\begin{array}{l}\text { Dickinson's kestrel } \\
\text { Falco dickinsoni }\end{array}$ & 0 & 0.04 & 0.25 & 0.05 & 0 & 0 \\
\hline $\begin{array}{l}\text { Brown-headed parrot } \\
\text { Poicephalus cryptoxanthus }\end{array}$ & 0.31 & 0.25 & 0.35 & 0.05 & 0.20 & 0 \\
\hline $\begin{array}{l}\text { Blue-spotted wood-dove } \\
\text { Turtur afer }\end{array}$ & 0.76 & 0.77 & 0.80 & 0.27 & 1.00 & 0.64 \\
\hline $\begin{array}{l}\text { Tambourine dove } \\
\text { Turtur tympanistria }\end{array}$ & 0.05 & 0.07 & 0.01 & 0 & 0 & 0 \\
\hline $\begin{array}{l}\text { Red-eyed dove } \\
\text { Streptopelia semitorquata }\end{array}$ & 0.31 & 0.57 & 0.65 & 0.51 & 0.67 & 0.27 \\
\hline $\begin{array}{l}\text { Pemba green pigeon } \\
\text { Treron pembaensis }\end{array}$ & 0.49 & 0.10 & 0.07 & 0 & 0.13 & 0.45 \\
\hline $\begin{array}{l}\text { Yellowbill } \\
\text { Ceuthmochares aereus }\end{array}$ & 0 & 0 & 0 & 0 & 0 & 0.18 \\
\hline $\begin{array}{l}\text { White-browed coucal } \\
\text { Centropus superciliosus }\end{array}$ & 0.14 & 0.40 & 0.44 & 0.80 & 0.40 & 0.09 \\
\hline $\begin{array}{l}\text { Pemba scops owl } \\
\text { Otus pembaensis }\end{array}$ & 1.00 & 0.83 & 0.19 & - & - & - \\
\hline $\begin{array}{l}\text { African pygmy kingfisher } \\
\text { Ipsidina picta }\end{array}$ & 0.04 & 0.01 & 0.02 & 0 & 0 & 0 \\
\hline $\begin{array}{l}\text { Mangrove kingfisher } \\
\text { Halcyon senegaloides }\end{array}$ & 0.92 & 0.61 & 0.22 & 0 & 0.60 & 0.27 \\
\hline $\begin{array}{l}\text { Broad-billed roller } \\
\text { Eurystomus glaucurus }\end{array}$ & 0.44 & 0.47 & 0.48 & 0.46 & 0.13 & 0 \\
\hline $\begin{array}{l}\text { Crowned hornbill } \\
\text { Tockus alboterminatus }\end{array}$ & 0.81 & 0.35 & 0.26 & 0.51 & 0.13 & 0.45 \\
\hline $\begin{array}{l}\text { Grassland pipit } \\
\text { Anthus cinnamomeus }\end{array}$ & 0 & 0.03 & 0.08 & 0.02 & 0 & 0 \\
\hline $\begin{array}{l}\text { Pemba black-bellied starling } \\
\text { Lamprotornis corruscus vaughani }\end{array}$ & 0.56 & 0.21 & 0.03 & 0.76 & 0 & 0.18 \\
\hline $\begin{array}{l}\text { Violet-backed starling } \\
\text { Cinnyricinclus leucogaster }\end{array}$ & 0 & 0.03 & 0.09 & 0 & 0 & 0 \\
\hline $\begin{array}{l}\text { Eurasian golden oriole } \\
\text { Oriolus oriolus }\end{array}$ & 0.02 & 0 & 0 & 0 & 0 & 0 \\
\hline $\begin{array}{l}\text { Pied crow } \\
\text { Corvus albus }\end{array}$ & 0.20 & 0.25 & 0.76 & 0.17 & 0.07 & 0.73 \\
\hline $\begin{array}{l}\text { Spotted flycatcher } \\
\text { Muscicapa striata }\end{array}$ & 0 & 0 & 0.03 & 0.10 & 0 & 0 \\
\hline $\begin{array}{l}\text { African paradise flycatcher } \\
\text { Terpsiphone viridis }\end{array}$ & 0.29 & 0.40 & 0.49 & 0.22 & 0.80 & 0.64 \\
\hline $\begin{array}{l}\text { Zitting cisticola } \\
\text { Cisticola juncidis }\end{array}$ & 0 & 0.02 & 0.15 & 0.88 & 0 & 0 \\
\hline $\begin{array}{l}\text { Pemba white-eye } \\
\text { Zosterops vaughani }\end{array}$ & 0.78 & 0.80 & 0.42 & 1.00 & 0.80 & 1.00 \\
\hline Pemba sunbird & 0.81 & 0.77 & 0.86 & 0.73 & 0.80 & 0.73 \\
\hline
\end{tabular}


Table 2 (continued)

\begin{tabular}{|c|c|c|c|c|c|c|}
\hline Habitat & Forest & Cloves & Farm & Scrub & Rubber & Coral rag forest \\
\hline \multicolumn{7}{|l|}{ Nectarinia pembae } \\
\hline Olive sunbird & 0.64 & 0.41 & 0.12 & 0.05 & 0.27 & 0.64 \\
\hline \multicolumn{7}{|l|}{ Nectarinia olivacea } \\
\hline $\begin{array}{l}\text { Southern grey-headed sparrow } \\
\text { Passer diffusus }\end{array}$ & 0 & 0.01 & 0.01 & 0.07 & 0 & 0 \\
\hline \multicolumn{7}{|l|}{ Passer diffusus } \\
\hline Grosbeak-weaver & 0 & 0 & 0.01 & 0 & 0 & 0 \\
\hline \multicolumn{7}{|l|}{ Amblyospiza albifrons } \\
\hline Black-winged red bishop & 0 & 0 & 0.04 & 0.22 & 0 & 0 \\
\hline \multicolumn{7}{|l|}{ Euplectes hordeaceus } \\
\hline Black-and-white mannikin & 0.02 & 0.18 & 0.16 & 0.27 & 0 & 0.09 \\
\hline \multicolumn{7}{|l|}{ Lonchura bicolor } \\
\hline Bronze mannikin & 0 & 0.08 & 0.20 & 0 & 0.07 & 0 \\
\hline \multicolumn{7}{|l|}{ Lonchura cucullata } \\
\hline Zebra waxbill & 0 & 0 & 0.01 & 0 & 0 & 0 \\
\hline Amandava subflava & & & & & & \\
\hline
\end{tabular}

a Sample size for scops owl is different, see text.

on Pemba. Aerial foragers like little swift (Apus affinis), African palm swift (Cypsiurus parvus), Madagascar beeeater (Merops (superciliosus) superciliosus) and wiretailed swallow (Hirundo smithii) were not included because they could not be seen in areas with closed canopy, although they were often present. Other species seen during our stay, but not during point counts, were Gabon nightjar (Caprimulgus fossi), house martin (Delichon urbica; one individual on 22/10/98 in Konde, the first record for the island), lesser striped swallow (Hirundo abyssinica), African reed warbler (Acrocephalus baeticatus), Java sparrow (Pada oryzivora) and house crow (Corvus splendens).

We performed 350 point counts for diurnal birds (including some points in border areas and in rare habitats) and 180 for scops owls, in a sample broadly representative of the whole of the Island of Pemba, although with a disproportionate emphasis in rare forest remains. All six known endemic birds were encountered frequently: Pemba African goshawk (Accipiter tachiro pembaensis, $20 \%$ of the counts), Pemba green pigeon (Treron pembaensis, 16\%), Pemba scops owl (Otus pembaensis, 67\%), Pemba black-bellied starling (Lamprotornis corruscus vaughani, 27\%), Pemba sunbird (Nectarinia pembae, $80 \%$ ) and Pemba white-eye (Zosterops vaughani, $70 \%$ ). The goshawk is rather inconspicuous and its frequency of occurrence in our samples is probably not low for a predatory bird, naturally living at comparatively low densities. However, the green pigeon seems to be relatively uncommon. On the other hand, the bronze-napped pigeon (Columba delegorguei), which may be occur as an endemic undescribed subspecies (Archer and Turner, 1993) was not observed during our survey.

With the exception of the Pemba sunbird, all endemic taxa showed significant differences in the frequency of occurrence between habitats, with farmland being much less favoured than forest or clove plantations (Fig. 2). The Pemba white-eye and the starling were recorded at highest frequency in the coral rag scrub, whereas the preferred habitats for the other species were the remnants of the tropical moist forest (Fig. 2).

The main structural difference between habitats related to tree cover. Canopy cover was highest in forest (mean $=73 \pm 11 \%, n=59$ ), lowest in agricultural land $(14 \pm 13 \%, n=106)$ and coral scrub $(2 \pm 4 \%, n=41)$, and intermediate in clove plantations $(45 \pm 24 \%, n=102)$. Undergrowth or scrub cover was also high in forest $(72 \pm 13 \%)$ and coral rag scrub $(87 \pm 9 \%)$, intermediate in clove plantations $(35 \pm 24 \%)$ and lowest in agricultural land $(11 \pm 12 \%)$. Within habitats, we could find no relationship between the variables measured (clove, coconut and total tree density indices, canopy cover and undergrowth cover) and the probability of occurrence of any of the endemics, with one notable exception: Pemba sunbirds were more likely to be found in areas with many coconut trees, both in farmland (logistic regression: $\left.G_{1}^{2}=5.74, n=106, P<0.02\right)$ and in clove plantations $\left(G_{1}^{2}=5.96, n=102, P<0.02\right)$. The relationship holds when using the total number of sunbirds detected per point count, instead of presence/absence data (Spearman rank correlation. Farmland: $r=0.27$, $P<0.01$; Cloves: $r=0.29, P<0.01)$.

\subsection{Food-plants of Pemba endemic birds}

Of the six endemic taxa, four (pigeon, starling, whiteeye and sunbird) rely more or less heavily on plants foods. We have no information on the diet of the two predatory species. The Pemba green pigeon is essentially frugivorous. Fruits are also eaten in large numbers by the omnivorous black-bellied starling and the Pemba white-eye. The Pemba sunbird is to a large extent nectarivorous, although it feeds also on insects and other 


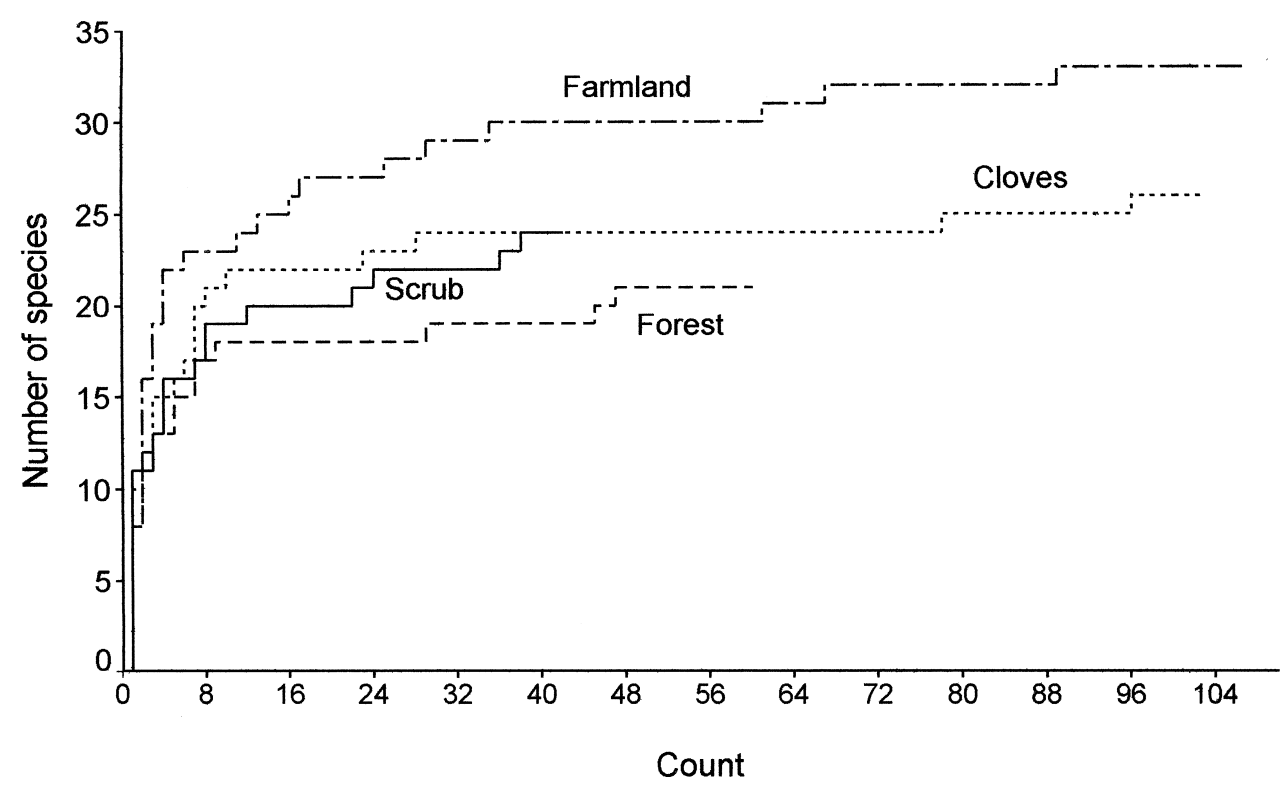

Fig. 1. Cumulative total of bird species recorded in each habitat as more point-counts were made.
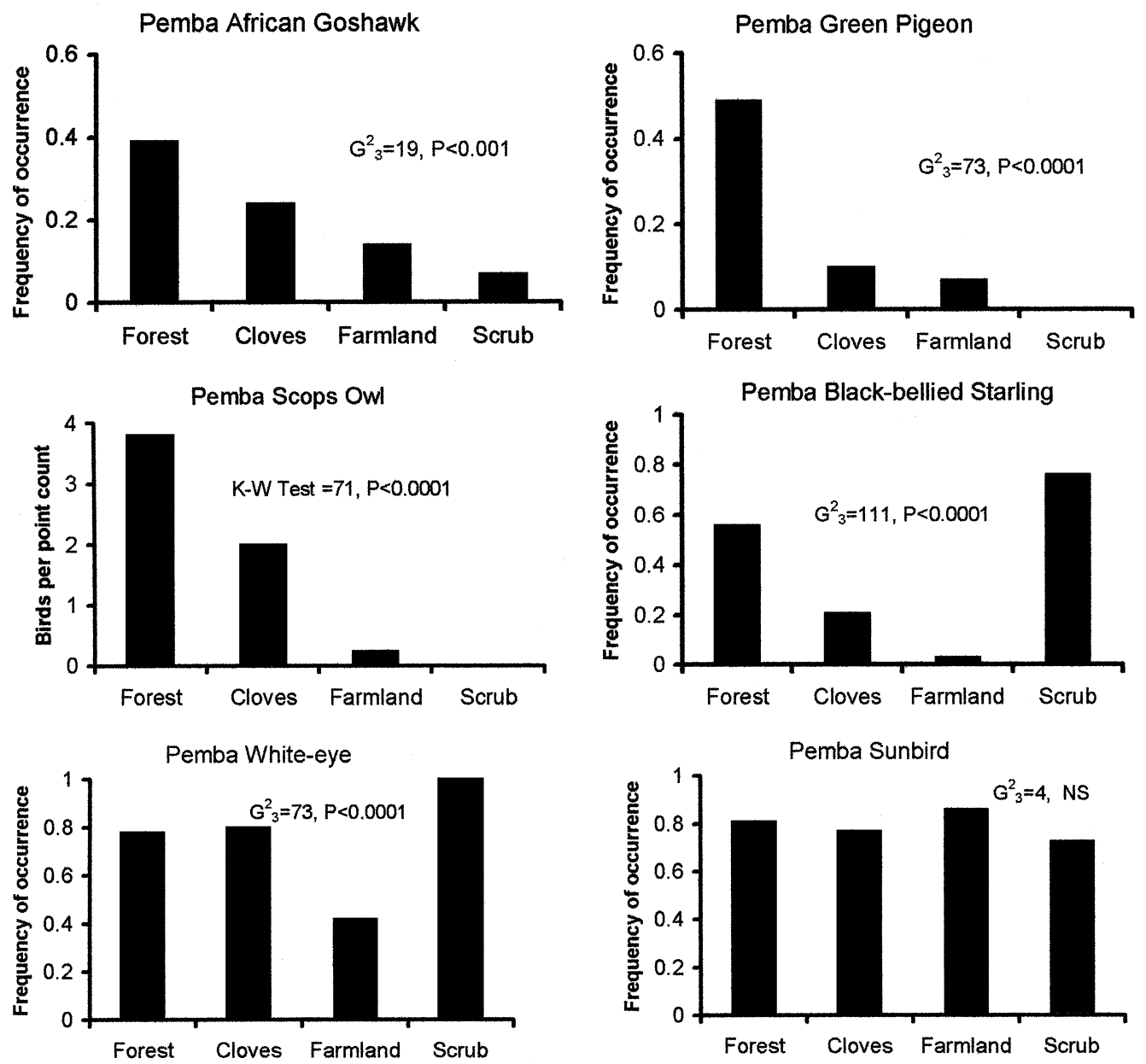

Fig. 2. Abundance of the six endemic bird taxa in the four main habitats of Pemba during the breeding season. Statistical tests compare the frequency of occurrence (or the median number of contacts per point count in the case of the scops owl) in different habitats. Note different scales in the graphs. 
invertebrates. White-eyes also feed on nectar, although their nectar sources in Pemba have not been documented.

Table 3 presents qualitative data on the important food plants for the endemic bird taxa in Pemba. Most of these plants are either commercial crops (e.g. cloves, coconut trees or cassava) or grow, more or less frequently, within clove plantations and agricultural land (Ficus sp., Croton sylvaticus, Antidesma venosum). However, other species are more commonly, or exclusively found in forests (e.g. Rauvolfia mombasiana). It is likely that other important forest species were overlooked by our survey, since observations within the forest and in the canopy were difficult.

\section{Discussion}

The results of this study underline the difficulties involved in trying to estimate distance to singing or calling birds even by experienced observers (see Bibby et al., 1992). The direction and magnitude of the errors are likely to vary with habitat structure, depending on the degree of sound attenuation (Sorjonen, 1983). This makes comparisons of relative densities problematic. Furthermore, several additional assumptions of the distance-sampling approach, for example, independence of individual records and maximum detection probability at zero distance, often are not met in tropical forest habitats (Bibby et al., 1992). In spite of these, density estimates derived from distance methods applied to auditory contacts are frequently published (e.g. Jacobs and Walker, 1999). Although this might be deemed the "best of a bad job" in some cases, we suggest that this method should be used with caution when trying to estimate the size of bird populations or compare densities between locations and habitats.

Our partial solution to these problems inherent in point count estimates was to compare the proportion of point counts in which a species was detected. It has to be noted that this is still not ideal, as the probability of recording presence/absence was also influenced by habitat structure, although probably less so than distance estimates. However, our conclusions concerning habitat selection by the endemic taxa are likely to be robust in relation to this factor, since most species showed higher frequency of occurrence in habitats with lower detection probabilities (i.e. closed forest).

Presence/absence data are not as informative as actual densities. However, it seems likely that the two types of abundance indices are highly correlated, as it has been found in a large-scale study in Britain (Gibbons et al., 1993). We believe that this should apply even better where comparisons between habitats are being made (as in our study) instead of geographical comparisons where the presence of a mosaic of habitats might

Table 3

Important food-plants of Pemba endemic birds

\begin{tabular}{|c|c|c|c|c|}
\hline Species & Pemba green pigeon & Black-bellied starling & Pemba white-eye & Pemba sunbird \\
\hline $\begin{array}{l}\text { Apocynaceae } \\
\text { Rauvolfia mombasiana (fruits) }\end{array}$ & & + & & \\
\hline $\begin{array}{l}\text { Euphorbiaceae } \\
\text { Margaritaria discoidea (fruits) } \\
\text { Antidesma venosum (fruits) } \\
\text { Croton sylvaticus (fruits) } \\
\text { Cassava Manihot esculenta (flowers) }\end{array}$ & $\begin{array}{l}+ \\
+\end{array}$ & $\begin{array}{l}+ \\
+ \\
+\end{array}$ & $\begin{array}{l}+ \\
+\end{array}$ & + \\
\hline $\begin{array}{l}\text { Moraceae } \\
\text { Ficus lutea (fruits) } \\
\text { Ficus natalensis (fruits) } \\
\text { Morus nigra (fruits) }\end{array}$ & $\begin{array}{l}+ \\
+\end{array}$ & + & + & \\
\hline $\begin{array}{l}\text { Sapindaceae } \\
\text { Beinbollia borbonica (fruits) }\end{array}$ & & + & & \\
\hline $\begin{array}{l}\text { Musaceae } \\
\text { Banana Musa sp. (flowers) }\end{array}$ & & & & + \\
\hline $\begin{array}{l}\text { Caricaceae } \\
\text { Papaya Carica papaya (flowers) }\end{array}$ & & & & + \\
\hline $\begin{array}{l}\text { Rutaceae } \\
\text { Clausena anisata (fruits) }\end{array}$ & & + & & \\
\hline $\begin{array}{l}\text { Myrtaceae } \\
\text { Clove Syzygium aromaticum (flowers) }\end{array}$ & & & & + \\
\hline $\begin{array}{l}\text { Palmae } \\
\text { Phoenix reclinata (flowers) } \\
\text { Betel-nut Palm Areca catech } \text { (fruits) }^{\mathrm{a}} \\
\text { Coconut palm Cocos nucifera (flowers) }\end{array}$ & + & & & $\begin{array}{l}+ \\
+\end{array}$ \\
\hline
\end{tabular}

a Referred by Urban et al. (1986). 
confound the results. Frequency data are less meaningful when they often approach maximum values (1, or $100 \%$ ). This was rarely the case for the endemic taxa in the habitats studied.

Very few bird species, and no endemics, were confined to the more "natural" habitats (forest and/or coral-rag scrub). This could be due to previous (and undetected) extinction of species unable to adapt to habitat changes, in which case those that are left are a biased sample of the original bird community. Alternatively, the changes were not dramatic enough to prevent birds from colonising new habitats. Clove plantations, for example, support good numbers of most typical forest species. It is interesting and somewhat surprising that forest bird communities were not more species-rich than clove plantation and farmland communities. Tropical forests usually display higher bird diversities than any other habitat (e.g. Terborgh et al., 1990). The great simplification of habitat structure as a result of forest clearance, and the proliferation of plantations and open terrain, has not resulted in a reduction in species diversity in the altered habitats of Pemba as far as we can judge from current bird distributions.

The higher species richness of farmland in our study should not be interpreted as suggesting that this habitat is of greater conservation value than native forest or scrub. Five out of six endemic taxa (i.e. those of greater conservation value) were relatively scarce in farmland despite its higher overall bird diversity. From this perspective, farmland has a low conservation value on Pemba, highlighting that the level of diversity alone is not an appropriate guideline for habitat assessment for conservation purposes [see Reid (1998) for a review of this issue].

According to breeding data presented by Pakenham (1979), our study was carried out during the breeding season of all the endemics, with the possible exception of the goshawk, for which the breeding season has not been clearly defined. The patches of habitat surveyed were large compared to normal home-ranges of species like the ones we studied, and therefore we believe that birds that we censused were not often crossing habitat boundaries during their daily routines. Therefore, it seems likely that many of those birds were actually nesting in the habitats where they were recorded, and therefore the values of abundance for each habitat reflect habitat value for breeding of the endemic taxa.

At the current time, clove plantations and coral rag scrub are the primary habitats for most endemic bird taxa on Pemba during the breeding season. Forest remnants hold high densities of these species, but because their coverage has been much reduced they can only support a small fraction of those bird populations. Coral rag scrub and forest are subject to shifting cultivation at increasingly short cycles. In addition, wood is over-harvested in those areas, resulting in habitat degradation (Leskinen et al., 1997). Clove plantations, although still very widespread, are decreasing in Pemba as the cloves become less commercially viable and trees are logged for different uses. Many plantations have been converted to open farmland, and few new ones are being created. It is not known whether this trend will persist in the medium and long-term. However, if it is the case, birds such as the Pemba green pigeon, the Pemba scops owl and the Pemba black-bellied starling could become seriously threatened. Such species do not seem to be able to adapt well to open farmland habitats. On the other hand, other species such as the Pemba sunbird, which feeds extensively on common crops and trees of the farmland, have adapted well and are of low conservation concern. The importance of planted species for these birds is illustrated by the positive relationship between the abundance of coconut trees and of sunbirds. It is possible that, for other frugivorous species, the suitability of altered habitats will depend on the maintenance of strong populations of the food-plant species detailed in this paper.

\section{Acknowledgements}

Paulo Catry benefited from a fellowship from Fundação para a Ciência e a Tecnologia, Portugal (Praxis XXI, BPD/16304/98) during the period covered by this research. We are most grateful to the following for funding the expedition to Pemba: BP Conservation Awards, the University of Glasgow, Glasgow University Veterinary Zoological Society, Carnegie Trust, Gilchrist Educational Trust, Karen Hansen Trust, Percy Sladen Memorial Trust, Mammal Society, David Sheperd Conservation Trust. The staff from the Commission for Natural Resources in Zanzibar and Pemba were most helpful at all stages of the project. P.A.R. Hockey, José Pedro Granadeiro and Richard Phillips commented on and improved earlier versions of the manuscript.

\section{References}

Abdullah, H.S., Ali, M.S., Kurikka, T., 1996. Ngezi Forest Reserve Management Plan. Zanzibar Forestry Development Project, Technical Paper No. 31.

Archer, A.L., Turner, D.A., 1993. Notes on the endemic species and some additional new birds occurring on Pemba Island. Tanzania. Scopus 16. 94-98.

Beentje, H.J., 1990. Botanical Assessment of Ngezi Forest, Pemba. Zanzibar Forestry Development Project, Technical Paper No. 1.

Bibby, C.J., Burgess, N.D., Hill, D.A., 1992. Bird Census Techniques, Academic Press, London.

Burgess, N.D., Mwasumbi, L.B., Hawthorne, W.J., Dickinson, A., Doggett, R.A., 1992. Preliminary assessment of the distribution, status and biological importance of coastal forests in Tanzania. Biological Conservation 62. 205-218.

Collar, N.J., Crosby, M.J., Stattersfield, A.J., 1994. Birds to Watch 2. The World List of Threatened Birds, BirdLife International, Cambridge. 
del Hoyo, J., Elliot, A., Sargatal, J. (Eds.), 1996. Handbook of the Birds of the World, Vol. 3. Hoatzin to Auks. Lynx Edicions, Barcelona.

Gibbons, D.W., Reid, J.B., Chapman, R.A., 1993. The new atlas of breeding birds in Britain and Ireland: 1988-1991, T. \& A.D. Poyser, London.

ICBP, 1992. Putting Biodiversity on the Map: Priority Areas for Global Conservation, International Council for Bird Preservation, Cambridge.

Jacobs, M.D., Walker, J.S., 1999. Density estimates of birds inhabiting fragments of cloud forest in Southern Ecuador. Bird Conservation International 9. 73-79.

Leskinen, J., Pohjonen, V.M., Ali, M.S., 1997. Woody Biomass Inventory of Zanzibar Islands. Zanzibar Forestry Development Project, Technical Paper No. 40.

Newton, I., 1998. Population Limitation in Birds, Academic Press, San Diego.

Pakenham, C.B.E., 1979. The Birds of Zanzibar and Pemba, British Ornithologists' Union, London.
Reid, W.V., 1998. Biodiversity hotspots. Trends Review in Ecology and Evolution 13. 275-280.

Sorjonen, J., 1983. Transmission of the two most characteristic phrases of the song of the Trush Nightingale Luscinia luscinia in different environmental conditions. Ornis Scandinavica 14. 278-288.

Stattersfield, A.J., Crosby, M.J., Long, A.J., Lodge, D.C., 1998. Endemic Bird Areas of the World. Priorities for Biodiversity Conservation, BirdLife International, Cambridge.

Terborgh, J., Robinson, S.K., Parker III, T.A., Munn, C.A., Pierpont, N., 1990. Structure and organization of an Amazonian forest bird community. Ecological Monographs 60. 213-238.

Urban, E.K., Fry, C.H., Keith, S. (Eds.), 1986. The Birds of Africa, Vol. II. Academic Press, London.

Vaughan, J.H., 1929. The birds of Zanzibar and Pemba. Ibis Series 12 (5). 577-608.

Vaughan, J.H., 1930. The birds of Zanzibar and Pemba. Ibis Series 12 (6). 1-48.

Zimmerman, D.A., Turner, D.A., Pearson, D.J., 1996. Birds of Kenya and Northern Tanzania. Christopher Helm, London. 